\title{
Spectrophotometric Determination of Bromhexine Hydrochloride by Azo-Dye Formation Reaction
}

\author{
Nabeel Sabeh Othman
}

Omer

\section{ఇ९्@ Shilan Ali}

\begin{abstract}
Chemistry Department / College of Science Mosul University

Received

12 / 09 / 2007

Accepted

05 / $11 / 2007$

الرلخص

يتضمن البحث طريقة طيفية لتقدير كميات متتاهية في الصغر من البرومهكسين

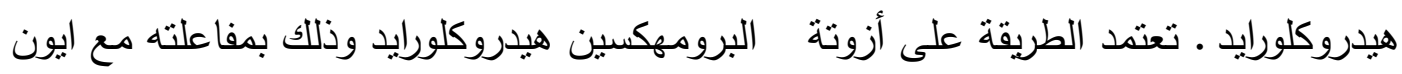

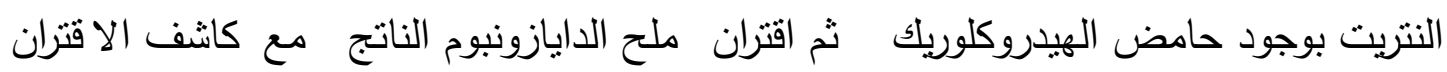

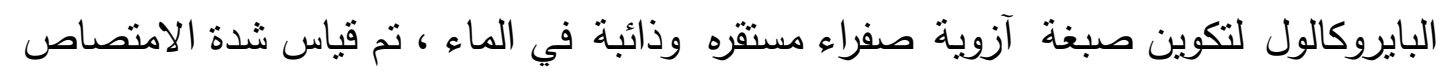

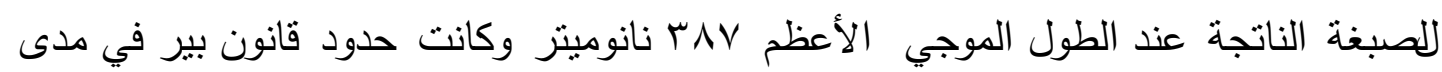

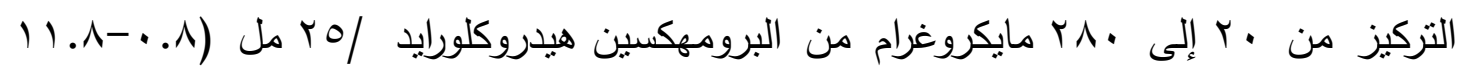

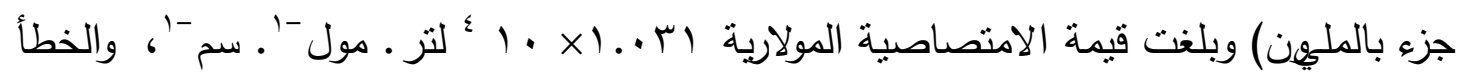

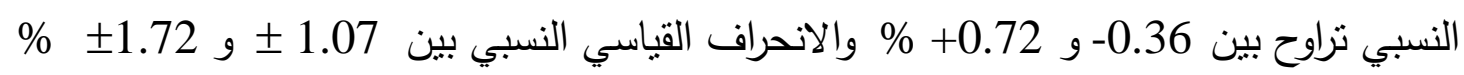
اعتمادا على مستوى تركيز البرومهكسين هيدروكلورايد . نم تطبيق الطريقة بنجاح في نقدير البرومهكسين هيدروكلورايد في مستحضراته الصيد لانية المختلفة.
\end{abstract}

\begin{abstract}
A spectrophotometric method for the assay of trace amounts of bromhexine- $\mathrm{HCl}$ based on the reaction of bromhexine- $\mathrm{HCl}$ with nitrite ion to form the corresponding diazonium salt followed by coupling reaction with pyrogallol in a acidic medium to form a stable and a soluble yellow azo dye with maximum absorption at $387 \mathrm{~nm}$. Beer's law is obeyed in the concentration range of $20-280 \mu \mathrm{g}$ of bromhexine- $\mathrm{HCl}$ in a final volume of $25 \mathrm{ml}(0.8-11.2 \mathrm{ppm})$ with a molar absorptivity of $1.031 \times 10^{4} \mathrm{~L} \cdot \mathrm{mol}^{-1} \cdot \mathrm{cm}^{-1}$, a relative error of -0.36 to $+0.72 \%$ and a relative standard deviation of \pm 1.07 to $\pm 1.72 \%$, depending on the concentration level of bromhexine-HCl. The method has been
\end{abstract}


successfully applied for the assay of bromhexine- $\mathrm{HCl}$ in various pharmaceutical preparations.

\section{INTRODUCTION}

Bromhexine is used for respiratory infections, such as the cold and influenza [1]. Bromhexine hydrochloride, N-(2-amino-3,5dibromophenylmethyl)-N-methyl-cyclohexylamine hydrochloride has the following structure[2]:

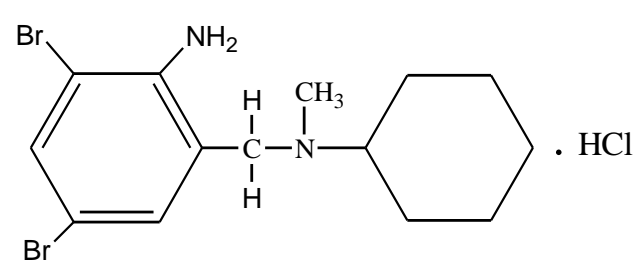

Bromhexine hydrochloride

Several spectrophotometric methods have been reported for the estimation of bromhexine- $\mathrm{HCl}$ using different reagents such as, rose Bengal in sulphuric acid medium [3], citric acid- $\mathrm{AC}_{2} \mathrm{O}$ in chloroform medium [4], p-dimethylamino benzaldehyde in highly acidic medium [5], bromocresol purple [6], tropaeoline, naphthalene blue $12 \mathrm{Br}$ and azocarmon Greact acidic dyes in non aqueous medium (chloroform)[7], $p$-dimethylaminobenzaldehyde in the presence of sodium dodecyl sulphate[8], after diazotisation, the corresponding bromhexin diazonium salt is coupled with a suitable agent such as, N-(1-naphthyl) ethylenediamine[9], 1-naphtylamine [10], resorcinol [11], 2-naphtho [12], orcinol [13]. Also, derivative and mults wavelength [14] and first derivative spectrophotometric methods [15] have been used in determination bromhexine-HCl. However, some of these proced-ure suffer from one or another disadvantage such as poor sensitivity [5] or require non- aqueous medium $[4,7,14]$.

The objective of the investigation reported in this paper is to evaluate a simple spectrophotometric method for the determination of bromhexine- $\mathrm{HCl}$. The method involves the diazotisation of bromhexine$\mathrm{HCl}$ and subsequent coupling with pyrogallol reagent as a coupling agent to form a highly coloured dye. that has been proved successfully for the assay of bromhexine- $\mathrm{HCl}$ in its different pharmaceutical preparations.

\section{Experimental}

\section{Instruments}


All spectrophotometric measurements are performed on Shimadzu UV-Visible Recording Spectrophotometer UV-160 by using $1 \mathrm{~cm}$ silica cell, pH meter type Philips PW 9420 is used for $\mathrm{pH}$ reading.

\section{Reagents}

All chemicals used in this investigation are of analytical - reagent grade, and bromhexine- $\mathrm{HCl}$ standard material is provided from general establishment for medical appliance and drugs / NDI - Mosul / Iraq.

\section{Solutions}

Bromhexine- $\mathbf{H C l}, 200 \mu g . m l^{-1}$. This solution is prepared by dissolving $0.2 \mathrm{~g}$ of pure bromhexine- $\mathrm{HCl}$ in $50 \mathrm{ml}$ of warmed distilled water to increase the solubility and then the solution is diluted to $100 \mathrm{ml}$ in a volumetric flask with distillated water.

Pyrogallol, 0.1\% (w/v). This solution is prepared freshly daily by dissolving $0.1 \mathrm{~g}$ of pyrogallol in $100 \mathrm{ml}$ distilled water.

Sodium nitrite solution, $1 \%(w / v)$. This solution is prepared by dissolving $1 \mathrm{~g}$ of sodium nitrite (BDH) in $100 \mathrm{ml}$ distilled water.

Sulphamic acid solution, 3\% (w/v). This solution is prepared by dissolving $3 \mathrm{~g}$ of sulphamic acid (Fluka) in $100 \mathrm{ml}$ distilled water.

Hydrochloric acid solution, 2N. This solution is prepared by diluting $17 \mathrm{ml}$ of concentrated acid $(11.8 \mathrm{~N})$ to $100 \mathrm{ml}$ with distilled water.

Bromhexine-HCl tablets solution, $80 \mu g . m l^{-1}$. Weighted and finely powdered 10 tablets (each one contain $8 \mathrm{mg}$ bromhexine- $\mathrm{HCl}$ ), an accurately weighed amount of powder equivalent to $0.008 \mathrm{~g}$ bromhexine$\mathrm{HCl}$ is dissolved in $2 \mathrm{ml}$ hydrochloric acid solution $(1 \mathrm{~N})$, then $50 \mathrm{ml}$ of warm distilled water is added and the solution is shaking to increase the solubility, filtered into $100 \mathrm{ml}$ calibrated flask, then the solution is completed to the volume with distilled water.

Bromhexine-HCl syrup solution, $80 \mu g \cdot m l^{-1}$. A $10 \mathrm{ml}$ of syrup (each $5 \mathrm{ml}$ contain $4 \mathrm{mg}$ bromhexine- $\mathrm{HCl}$ ) is transferred into a $100 \mathrm{ml}$ calibrated flask and the total volume is diluted with distilled water.

Bromhexine-HCl injection solution, $80 \mu \mathrm{g} . \mathrm{ml}^{-1}$. This solution is prepared by diluted $4 \mathrm{ml}$ of bromhexine- $\mathrm{HCl}$ injection solution (each $2 \mathrm{ml}$ contains $4 \mathrm{mg}$ bromhexine- $\mathrm{HCl}$ ), with distilled water in $100 \mathrm{ml}$ calibrated flask.

\section{Procedure and calibration graph}

To a series of $25-\mathrm{ml}$ calibrated flasks transfer $0.2-3.2 \mathrm{ml}$ of bromhexine- $\mathrm{HCl}$ solution (equivalent to $100 \mu \mathrm{g} \cdot \mathrm{ml}^{-1}$ bromhexine- $\mathrm{HCl}$ ), then $5 \mathrm{ml}$ of $2 \mathrm{~N}$ hydrochloric acid and $0.4 \mathrm{ml}$ of $1 \%(\mathrm{w} / \mathrm{v})$ sodium nitrite solution are added and the mixture is allowed to stand for 3 minute and then $0.3 \mathrm{ml}$ of $3 \%(\mathrm{w} / \mathrm{v})$ sulphamic acid solution is added with occasional 
shaking for 5 minute. After that a $4 \mathrm{ml}$ of $0.1 \%$ (w/v) pyrogallol was added. Then the solutions let to stand for 10 minutes at room temperature before the volumes are completed to the mark with distilled water, the absorbance is read at $387 \mathrm{~nm}$ against the reagent blank. A linear calibration graph is obtained over the concentration range of $20-280 \mu \mathrm{g}$ bromhexine-HCl / $25 \mathrm{ml}$

(0.8-11.2 ppm) and a concentration above $280 \mu \mathrm{g} / 25 \mathrm{ml}$ gives a negative deviation (Fig. 1). The molar absorptivity has been found to be $1.031 \times 10^{4} 1 . \mathrm{mol}^{-1} \cdot \mathrm{cm}^{-1}$.

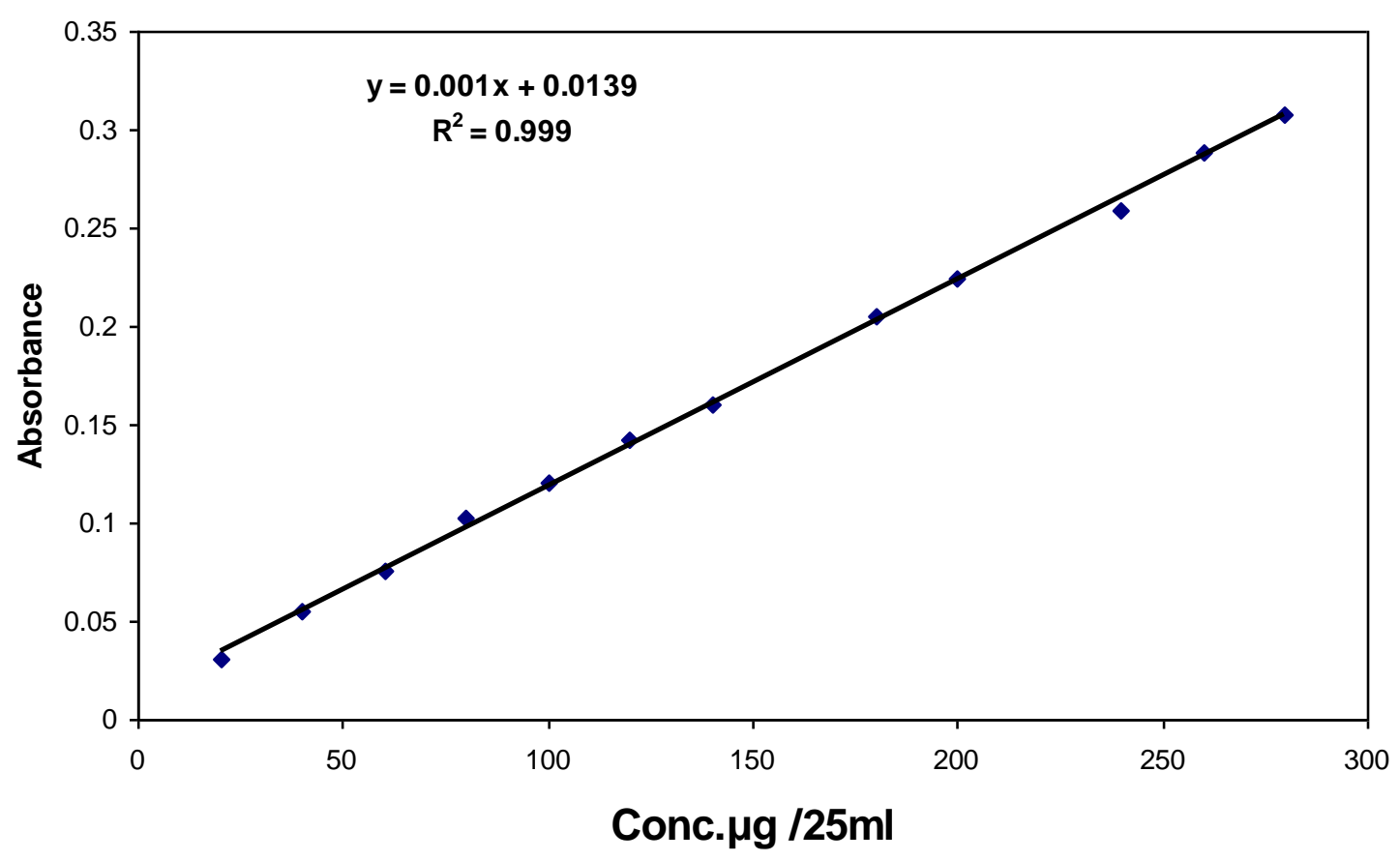

Fig. 1. Calibration graph of bromhexine-HCl determination

\section{Results and Discussion}

During the investigation, bromhexine- $\mathrm{HCl}$ solution equivalent to $200 \mu \mathrm{g} \cdot \mathrm{ml}^{-1}$ bromhexine- $\mathrm{HCl}$ is taken and the final volumes are brought to $25 \mathrm{ml}$ with distilled water.

\section{Effect of acid}

Different amounts and types of acids have been used in diazotisation of bromhexine- $\mathrm{HCl}$, the results show that the diazotization and then the formation of the dye needs highly acidic medium due to the presence of two bulky bromo group neighbouring the amino group, hence $5 \mathrm{ml}$ of $2 \mathrm{~N} \mathrm{HCl}$ has been selected for subsequent experiments (Table 1). 
Table 1. Effect of acids on absorbance and colour contrast

\begin{tabular}{|c||c|c|c|c|c|c|c|c||}
\hline \multirow{2}{*}{$\begin{array}{c}\text { 2N Acid } \\
\text { solution } \\
\text { used }\end{array}$} & \multicolumn{6}{|c|}{ Absorbance and colour contrast / ml of acid used } \\
\cline { 2 - 10 } & \multicolumn{2}{|c|}{$\mathbf{0 . 5}$} & \multicolumn{2}{|c|}{$\mathbf{2 . 5}$} & \multicolumn{2}{|c|}{$\mathbf{5 . 0}$} & \multicolumn{2}{c|}{$\mathbf{6 . 0}$} \\
\cline { 2 - 10 } & $\mathbf{A}^{*}$ & $\Delta \lambda * *, n m$ & $\mathbf{A}$ & $\Delta \lambda, \mathbf{n m}$ & $\mathbf{A}$ & $\Delta \lambda, \mathbf{n m}$ & $\mathbf{A}$ & $\Delta \lambda, \mathbf{n m}$ \\
\hline \hline $\mathrm{HCl}$ & 0.130 & 108 & 0.205 & 111 & 0.215 & 112 & 0.203 & 106 \\
\hline $\mathrm{HNO}_{3}$ & 0.124 & 108 & 0.192 & 112 & 0.162 & 109 & 0.157 & 111 \\
\hline $\mathrm{H}_{2} \mathrm{SO}_{4}$ & 0.106 & 104 & 0.160 & 102 & 0.169 & 110 & 0.163 & 113 \\
\hline $\mathrm{CH}_{3} \mathrm{COOH}$ & 0.097 & 29 & 0.108 & 30 & 0.088 & 29 & 0.090 & 30 \\
\hline
\end{tabular}

$* \Delta \lambda=\lambda_{\max } \mathrm{S}-\lambda_{\max } \mathrm{B}$ Where $\mathrm{S}=$ The dye, $\mathrm{B}=$ Blank

Effect of sodium nitrite amount and time

The maximum absorbance reading is obtained by adding $0.4 \mathrm{ml}$ of $1 \%$ sodium nitrite with 3 minutes of reaction time (Table2).

Table 2. Effect of sodium nitrite amounts and time on the absorbance of bromhexine-HCl

\begin{tabular}{|c||c|c|c|c|c|c|c|}
\hline \multirow{2}{*}{$\begin{array}{c}\text { ml of 1\% } \\
\text { NaNO } \\
\text { solution }\end{array}$} & \multicolumn{7}{|c|}{ Absorbance / minute standing time } \\
\cline { 2 - 8 } & $\mathbf{0}$ & $\mathbf{1}$ & $\mathbf{2}$ & $\mathbf{3}$ & $\mathbf{4}$ & $\mathbf{5}$ & $\mathbf{7}$ \\
\hline \hline 0.1 & 0.165 & 0.145 & 0.173 & 0.175 & 0.178 & 0.174 & 0.172 \\
\hline 0.2 & 0.195 & 0.188 & 0.178 & 0.175 & 0.182 & 0.180 & 0.168 \\
\hline 0.3 & 0.200 & 0.197 & 0.198 & 0.190 & 0.177 & 0.175 & 0.171 \\
\hline 0.4 & 0.220 & 0.216 & 0.218 & 0.222 & 0.208 & 0.205 & 0.203 \\
\hline 0.5 & 0.189 & 0.187 & 0.213 & 0.215 & 0.187 & 0.199 & 0.200 \\
\hline \hline
\end{tabular}




\section{Effect of sulphamic acid amounts and time}

The excess of nitrite can be removed by the addition of sulphamic acid solution [16]. The effect of sulphamic acid amount and time has been studied. (Table3)

Table 3. Effect of sulphamic acid amounts and time on the absorbance of bromhexine-HCl

\begin{tabular}{|c|c|c|c|c|c|c|c|c|}
\hline \multirow{2}{*}{$\begin{array}{c}\text { ml of } 3 \% \\
\text { Sulphamic } \\
\text { acid solution }\end{array}$} & \multirow{2}{*}{ Variable } & \multicolumn{7}{|c|}{ Absorbance/minute standing time } \\
\hline & & 0 & 1 & 2 & 3 & 4 & 5 & 7 \\
\hline \multirow{2}{*}{ 0.0. } & Sample $=S$ & 0.075 & 0.093 & 0.072 & 0.104 & 0.095 & 0.020 & 0.068 \\
\hline & Blank $=\mathrm{B}$ & 0.554 & 0.589 & 0.657 & 0.617 & 0.667 & 0.794 & 0.945 \\
\hline \multirow{2}{*}{0.2} & $\mathrm{~S}$ & 0.194 & 0.182 & 0.180 & 0.176 & 0.174 & 0.173 & 0.160 \\
\hline & B & 0.098 & 0.078 & 0.045 & 0.039 & 0.038 & 0.037 & 0.034 \\
\hline \multirow{2}{*}{0.30} & $S$ & 0.172 & 0.200 & 0.202 & 0.203 & 0.216 & 0.225 & 0.195 \\
\hline & B & 0.099 & 0.051 & 0.042 & 0.040 & 0.034 & 0.027 & 0.034 \\
\hline \multirow{2}{*}{0.4} & $S$ & 0.179 & 0.199 & 0.187 & 0.202 & 0.199 & 0.187 & 0.158 \\
\hline & B & 0.088 & 0.049 & 0.033 & 0.026 & 0.025 & 0.023 & 0.020 \\
\hline
\end{tabular}

The results in the table 3 indicate that $0.3 \mathrm{ml}$ of sulphamic acid solution $(3 \%, \mathrm{w} / \mathrm{v})$ with 5 minute as standing time for the reaction give the most suitable effect on the intensity of the azo-dye.

\section{Effect of pyrogallol amount on absorbance}

The effect of pyrogallol amount on the absorbance of the dye has been studied. From the results, it can be observed that $4 \mathrm{ml}$ of $0.1 \%$ pyrogallol is the more suitable amount which gives the highest value of intensity for the azo-dye formed and the highest value of correlation coefficient (Table 4).

Table 4. Effect of coupling agent amount on absorbance

\begin{tabular}{|c||c|c|c|c|c|c|c||}
\hline \multirow{2}{*}{$\begin{array}{c}\text { ml of } \\
\text { Pyrogallol } \\
\text { solution (0.1\%) }\end{array}$} & \multicolumn{6}{|c||}{ Absorbance/ $\mu$ g bromhexine-HCl in 25 ml } \\
\cline { 2 - 9 } & $\mathbf{4 0}$ & $\mathbf{8 0}$ & $\mathbf{1 2 0}$ & $\mathbf{1 8 0}$ & $\mathbf{2 0 0}$ & $\mathbf{2 4 0}$ & $\mathbf{r}$ \\
\hline \hline $\mathbf{2}$ & 0.048 & 0.084 & 0.130 & 0.175 & 0.192 & 0.219 & 0.99674 \\
\hline $\mathbf{3}$ & 0.052 & 0.100 & 0.138 & 0.201 & 0.216 & 0.248 & 0.99793 \\
\hline $\mathbf{4}$ & 0.055 & 0.102 & 0.142 & 0.205 & 0.228 & 0.259 & 0.99877 \\
\hline $\mathbf{5}$ & 0.051 & 0.092 & 0.140 & 0.198 & 0.215 & 0.242 & 0.99662 \\
\hline
\end{tabular}




\section{Effect of time}

\begin{tabular}{|c|c|c|c|c|c|c|c|c|c|c|}
\hline \multirow{2}{*}{$\begin{array}{l}\text { Mg of } \\
\text { Bromhexine- } \\
\text { HCl present }\end{array}$} & \multicolumn{10}{|c|}{ Absorbance / minute standing time } \\
\hline & $\mathbf{0}$ & 5 & 10 & 15 & 25 & 30 & 35 & 45 & 55 & 60 \\
\hline 80 & 0.107 & 0.114 & 0.120 & 0.119 & 0.118 & 0.118 & 0.117 & 0.115 & 0.114 & 0.114 \\
\hline 140 & 0.157 & 0.162 & 0.160 & 0.159 & 0.155 & 0.154 & 0.154 & 0.152 & 0.151 & 0.151 \\
\hline 200 & 0.223 & 0.229 & 0.230 & 0.230 & 0.228 & 0.228 & 0.228 & 0.224 & 0.223 & 0.222 \\
\hline
\end{tabular}

The coloured azo dye developed rapidly after addition of pyrogallol and the stability period (within the first hour of stability) is sufficient to perform several measurements and the results are given in table 5.

Table 5. The effect of time and bromhexine-HCl amount on absorbance

\section{Final absorption spectra}

The absorption spectra of the yellow azo dye formed by coupling of diazotised bromhexine- $\mathrm{HCl}$ with pyrogallol in acidic medium shows a maximum absorption at $387 \mathrm{~nm}$. The reagent blank gives very weak absorption at this wavelength (Fig. 2).

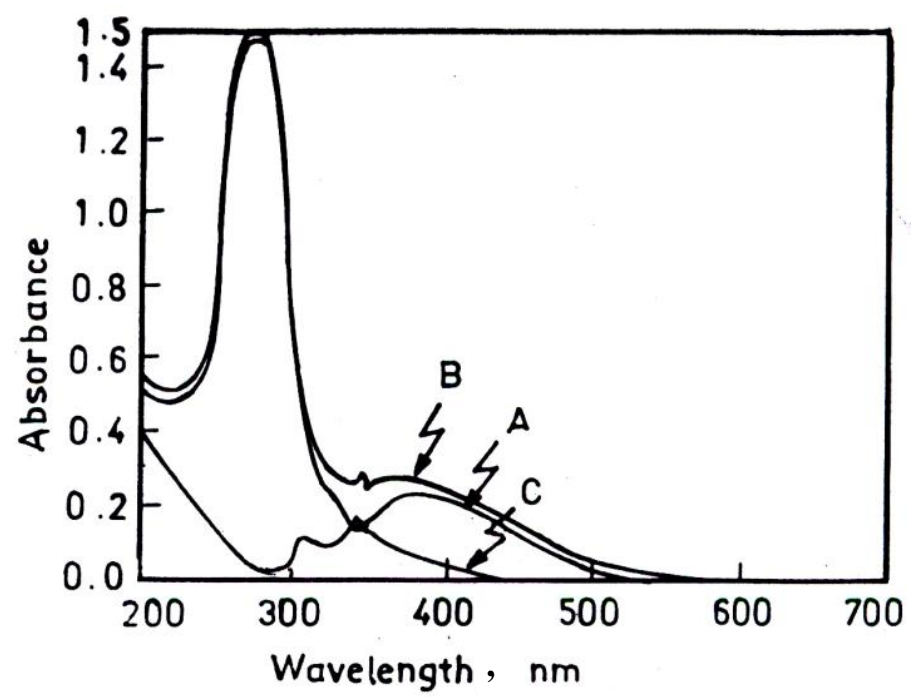

Fig.2: Absorption spectra of $200 \mu \mathrm{g}$ bromhexine- $\mathrm{HCl} / 25 \mathrm{ml}$ treated according to the recommended procedure and measured against (A) 
reagent blank, (B) distilled water and $(\mathrm{C})$ reagent blank measured against distilled water.

Nature of the dye

The stoichiometry of the azo dye thus formed by reaction of diazotised bromhexine [BH]with pyrogallol [PY] is investigated by applying the continuous variations method (Job's method)and mol ratio method. The results indicate that the azo-dye was formed in the ratio of 1:1diazotised bromhexine to pyrogallol (Fig.3 and Fig.4).

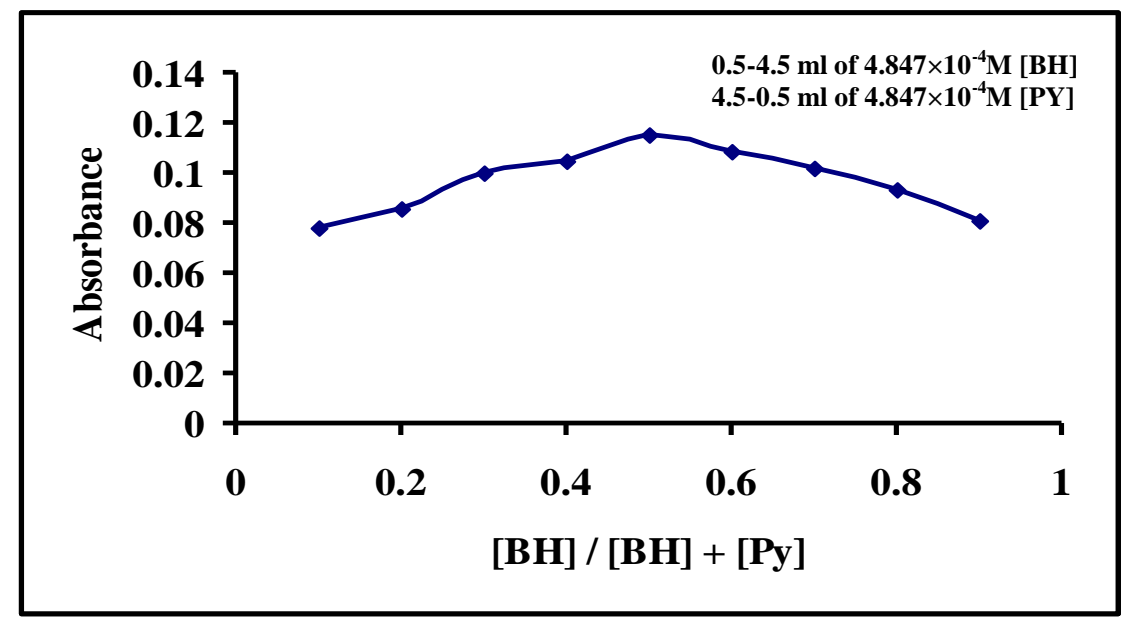

Fig.3: Job's plot for bromhexine-pyrogallol

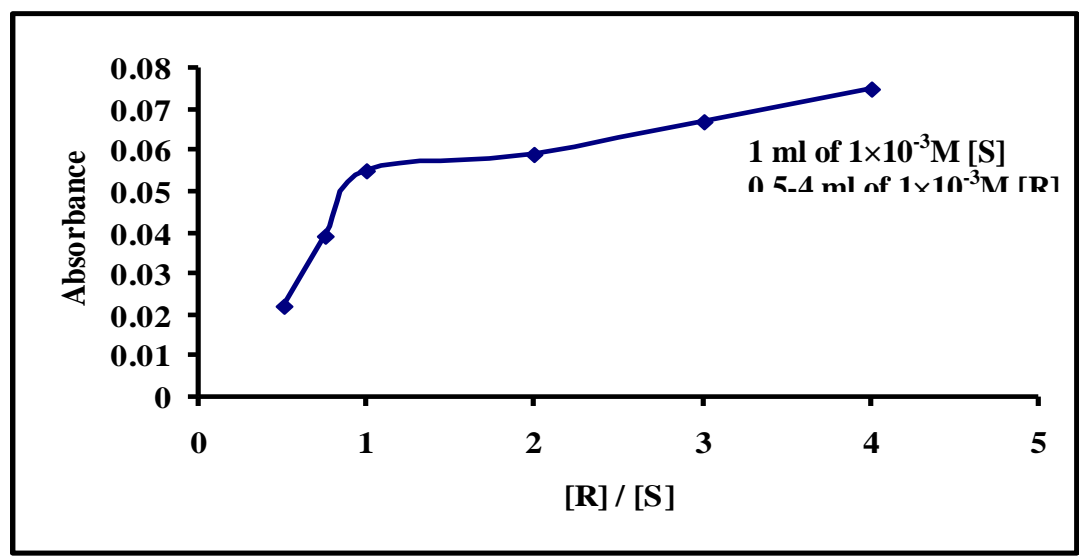

Fig.4: Mole ratio plot for bromhexine-pyrogallol

Therefore the azo-dye may have the following suggested structure:

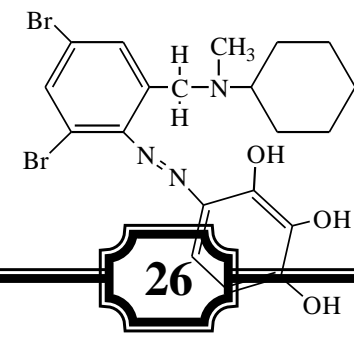




\section{Interference}

$$
\text { Yellow azo-dye }
$$

The effect of some foreign compounds which often accompanied pharmaceutical preparations were studied by adding three different amounts $(100,500$ and $1000 \mu \mathrm{g})$ to $100 \mu \mathrm{g}$ bromhexine- $\mathrm{HCl}$ in a final volume $25 \mathrm{ml}$ (Table 6).

Table 6: Effect of foreign compounds for assay of bromhexine-HCl

\begin{tabular}{|c|c|c|c|}
\hline \multirow{2}{*}{$\begin{array}{c}\text { Foreign } \\
\text { compound }\end{array}$} & \multicolumn{3}{|c|}{$\begin{array}{c}\text { Recovery (\%) of } 200 \mu \mathrm{g} \text { bromhexine-HCl per } \boldsymbol{\mu g} \\
\text { foreign compound added }\end{array}$} \\
\cline { 2 - 4 } & $\mathbf{1 0 0}$ & $\mathbf{5 0 0}$ & $\mathbf{1 0 0 0}$ \\
\hline Glucose & 99.56 & 97.39 & 97.82 \\
\hline Glycerin & 99.13 & 96.52 & 95.65 \\
\hline Lactose & 98.78 & 98.26 & 97.39 \\
\hline Starch & 96.93 & 92.17 & 91.73 \\
\hline \hline
\end{tabular}

The results in table 6 indicated that the studied foreign compounds do not interfere in determination of bromhexine- $\mathrm{HCl}$ by using the proposed method. An error not more than of $\pm 3 \%$ in the absorbance readings is considered tolerable from that of the bromhexine- $\mathrm{HCl}$ alone.

\section{Accuracy and precision.}

To check the accuracy and precision of the method, bromhexine$\mathrm{HCl}$ is determined at three different concentrations. The relative error\% and relative standard deviation\% results indicate the high accuracy and precision of the proposed method (Table 7).

Table 7. Accuracy and precision

\begin{tabular}{|c|c|c|}
\hline $\begin{array}{c}\text { Amount of bromhexine- } \\
\text { HCl taken, } \boldsymbol{\mu g}\end{array}$ & $\begin{array}{c}\text { Relative error, } \\
\mathbf{\%}^{*}\end{array}$ & $\begin{array}{c}\text { Relative standard } \\
\text { deviation, } \% *\end{array}$ \\
\hline \hline 80 & +0.72 & \pm 1.72 \\
\hline
\end{tabular}


Spectrophotometric Determination of Bromhexine Hydrochloride ...

\begin{tabular}{|c|c|c|}
\hline 140 & +0.58 & \pm 1.42 \\
\hline 200 & -0.36 & \pm 1.07 \\
\hline
\end{tabular}

* Average of five determinations

\section{Analytical application}

The proposed method is applied to assay bromhexine- $\mathrm{HCl}$ in different pharmaceutical preparations (syrup, tablet and injection). On applying proposed procedure, good recovery is obtained as shown in table 8.

Table8. Analytical applications

\begin{tabular}{|c|c|c|c|}
\hline $\begin{array}{c}\text { Pharmaceutical } \\
\text { preparation }\end{array}$ & $\begin{array}{l}\mu \mathrm{g} \text { bromhexine- } \\
\mathrm{HCl} \text { present } / 25 \mathrm{ml}\end{array}$ & $\begin{array}{c}\mu \mathrm{g} \text { bromhexine-HCl } \\
\text { measured } / 25 \mathrm{ml}\end{array}$ & $\begin{array}{l}\text { Recovery* } \\
(\%)\end{array}$ \\
\hline \multirow{3}{*}{$\begin{array}{c}\text { Solvodine syrup, } 4 \mathrm{mg} \\
\text { bromohexine- } \mathrm{HCl} / 5 \mathrm{ml} \\
\text { (S.D.I. Iraq) }\end{array}$} & 112 & 112.88 & 100.78 \\
\hline & 160 & 160.88 & 100.55 \\
\hline & 194 & 190.43 & 98.16 \\
\hline \multirow{3}{*}{$\begin{array}{c}\text { Solvodin tablet } 8.0 \mathrm{mg} \\
\text { bromhexine-HCl/ tablet, } \\
\text { (S.D.I-Iraq }\end{array}$} & 112 & 109.28 & 97.57 \\
\hline & 160 & 158.19 & 98.87 \\
\hline & 194 & 192.19 & 99.07 \\
\hline \multirow{3}{*}{$\begin{array}{l}\text { Bromohexine- } \mathrm{HCl} \\
\text { injection, } 4 m g / 2 m l \\
\text { (Ibn Hayan, Syria) }\end{array}$} & 112 & 114.57 & 102.29 \\
\hline & 160 & 160.00 & 100.00 \\
\hline & 194 & 195.70 & 100.88 \\
\hline
\end{tabular}

*Average for five determinations

\section{Evaluation of the proposed method}

According to the difficulties of using the standard method for determination of bromhexine- $\mathrm{HCl}$ in its pharmaceutical preparation, so that standard addition method has been used in order to prove that the proposed method is applied in the determination of bromhexine- $\mathrm{HCl}$ without interferences (Table 9 and Fig.5)

Table 9: The results of standard addition method

\begin{tabular}{|c|c|c|c|}
\hline $\begin{array}{c}\text { Pharmaceutical } \\
\text { preparation }\end{array}$ & $\begin{array}{c}\mu \mathrm{g} \text { paracetamol } \\
\text { present } / 25 \mathrm{ml}\end{array}$ & $\begin{array}{l}\mu \mathrm{g} \text { paracetamol } \\
\text { measured } / 25 \mathrm{ml}\end{array}$ & $\begin{array}{c}\text { Recovery* } \\
(\%)\end{array}$ \\
\hline \multirow{2}{*}{$\begin{array}{c}\text { Solvodine syrup, } 4 \mathrm{mg} \\
\text { bromohexine-HCl/5 ml } \\
\text { (S.D.I. Iraq) }\end{array}$} & 80 & 82.50 & 103.12 \\
\hline & 160 & 164.00 & 102.50 \\
\hline \multirow{2}{*}{$\begin{array}{c}\text { Solvodin tablet } 8.0 \mathrm{mg} \\
\text { bromhexine-HCl/ tablet, } \\
\text { (S.D.I-Iraq ) }\end{array}$} & 80 & 80.00 & 100.00 \\
\hline & 160 & 161.00 & 100.65 \\
\hline
\end{tabular}


Nabeel Sabeh Othman \& Shilan Ali Omer

\begin{tabular}{|c|c|c|c|}
\hline \multirow{2}{*}{$\begin{array}{c}\text { Bromohexine-HCl} \\
\text { injection, 4mg/2ml (Ibn } \\
\text { Hayan, Syria) }\end{array}$} & 80 & 83.00 & 103.75 \\
\hline & 160 & 162.00 & 101.25 \\
\hline
\end{tabular}

*Average of three determinations
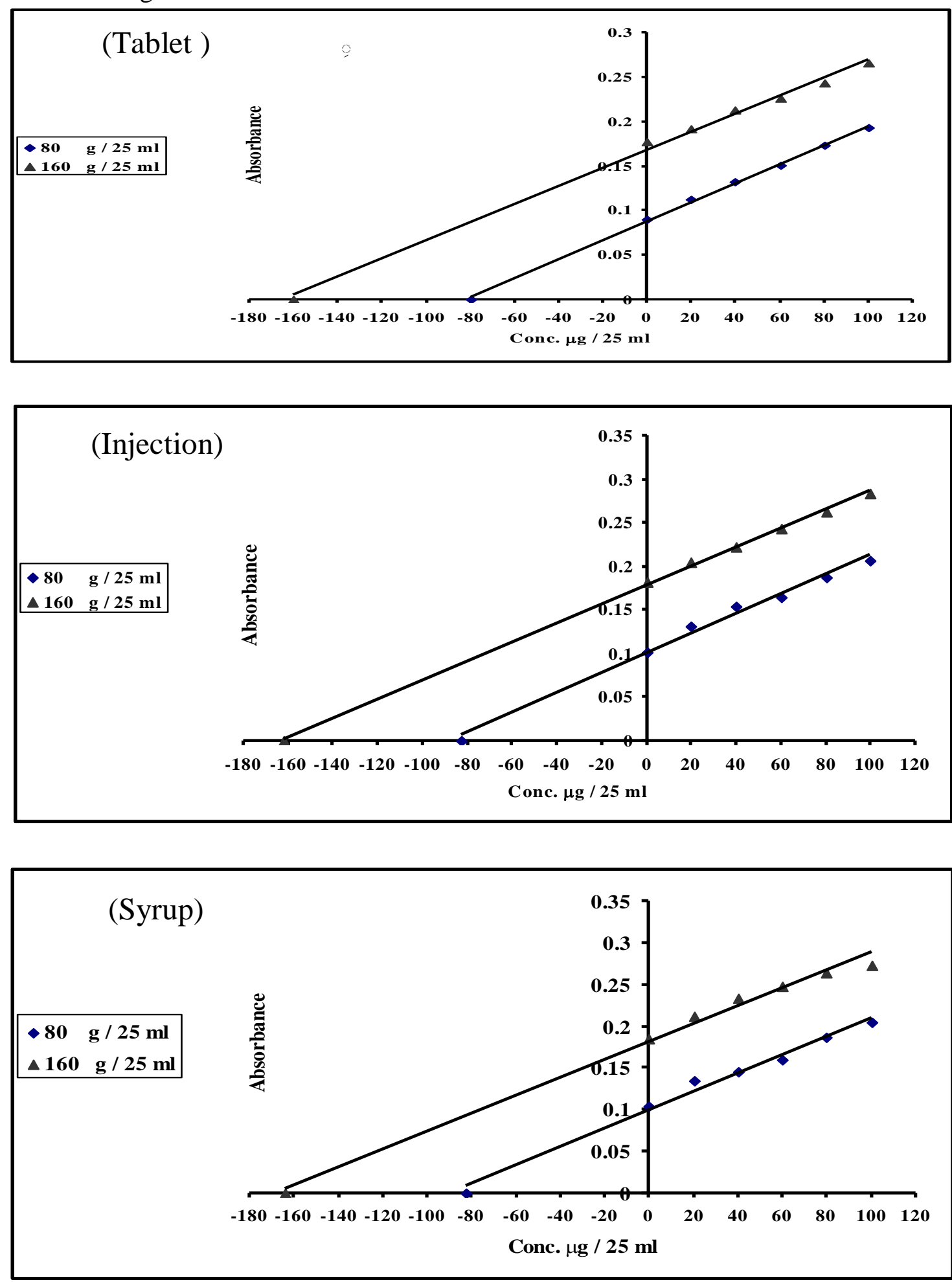

Fig. 5: Graphs of standard addition method for the determination of bromhexine- $\mathrm{HCl}$ in pharmaceutical preparations 
The results in table 9 and fig. 5 indicated that the proposed method can be used in determination of bromhexine- $\mathrm{HCl}$ with satisfactory results.

\section{Comparison of the methods}

Table 10 shows the comparison between some of analytical variables obtained from the present method with those of the recent spectrophotometric methods.

Table 10: The comparison of the methods

\begin{tabular}{|c|c|c|c|}
\hline Analytical parameters & $\begin{array}{l}\text { Present } \\
\text { method }\end{array}$ & $\begin{array}{c}\text { Literature } \\
\text { method }^{(8)}\end{array}$ & $\begin{array}{l}\text { Literature } \\
\text { method }^{(10)}\end{array}$ \\
\hline $\mathrm{pH}$ & 1.34 & 1.6 & $\ldots$ \\
\hline Temperature $\left({ }^{\circ} \mathrm{C}\right)$ & $\begin{array}{c}\text { Room } \\
\text { temperature }\end{array}$ & $\begin{array}{c}\text { Room } \\
\text { temperature }\end{array}$ & $\begin{array}{c}\text { Room } \\
\text { temperature }\end{array}$ \\
\hline$\lambda_{\max }(\mathrm{nm})$ & 387 & 430 & 478 \\
\hline Medium of reaction & Aqueous & Aqueous & Aqueous \\
\hline Reagent & Pyrogallol & $\begin{array}{c}p \text {-Dimethyl } \\
\text { amino } \\
\text { benzaldehyde } \\
\text { in presence of } \\
\text { sodium dodcyl } \\
\text { sulphate }\end{array}$ & $\begin{array}{l}\text { 1-Naphthyl } \\
\text { amine }\end{array}$ \\
\hline Beer's law range (ppm) & $0.8-11.2$ & $0.41-82.5$ & $2-8$ \\
\hline $\begin{array}{l}\text { Molar absorptivity } \\
\left(1 . \mathrm{mol}^{-1} \cdot \mathrm{cm}^{-1}\right)\end{array}$ & $1.031 \times 10^{4}$ & $0.36 \times 10^{4}$ & $\ldots$ \\
\hline $\operatorname{RSD}(\%)$ & $\leq 1.72$ & $\leq 3.5$ & $\ldots$ \\
\hline $\begin{array}{l}\text { Stability of the colour } \\
\text { (minute) }\end{array}$ & 60 & $\ldots$ & 1440 \\
\hline Colour of the product & Yellow & Yellow & Orange \\
\hline Application of the method & $\begin{array}{l}\text { Has been } \\
\text { applied to the } \\
\text { assay of } \\
\text { bromhexine } \\
\text { hydrochloride }\end{array}$ & $\begin{array}{l}\text { Has been } \\
\text { applied to the } \\
\text { assay of } \\
\text { bromhexine } \\
\text { hydrochloride }\end{array}$ & $\begin{array}{c}\text { Has been } \\
\text { applied to the } \\
\text { assay of } \\
\text { bromhexine } \\
\text { hydrochloride }\end{array}$ \\
\hline
\end{tabular}




\begin{tabular}{||l|c|c|c||}
\hline & $\begin{array}{c}\text { in } \\
\text { pharmaceutical } \\
\text { preparations } \\
\text { (tablets, } \\
\text { injection and } \\
\text { suspensions) }\end{array}$ & $\begin{array}{c}\text { in } \\
\text { pharmaceutical } \\
\text { preparations } \\
\text { (tablets and } \\
\text { suspensions) }\end{array}$ & $\begin{array}{c}\text { in } \\
\text { pharmaceutical } \\
\text { preparations }\end{array}$ \\
\end{tabular}

The results in table 10 shows that the suggested method for the determination of bromhexine- $\mathrm{HCl}$ is the more sensitive.

\section{Conclution}

The proposed method for the determination of bromhexine- $\mathrm{HCl}$ in pharmaceutical preparations is simple and sensitive. The azo-dye formed is fairly soluble in aqueous solution. The statistical analysis of the result indicates that the method has good accuracy (average relative error between -0.36 to $+0.72 \%$ ) and good precision(average relative standard deviation not more than $1.72 \%$ ).

\section{References}

1. Bub O.; and Friedrich L., (2002), Ullman's Encyclopedia of Industrial Chemistry. 6th Edn. Electronic Release.

2. "British Pharmacopeia on CD-ROM", $3^{\text {rd }}$ Edn., System Simulation Ltd, the stationary office, London, (2000).

3. Ganapathi P., Raju N. and Kumar G., East Pharm., (1999), 42, 135.

4. Shingbal D. and Nark R., Indian drugs, (1985), 22, 600; Chem. Abst., 104, 10729z.

5. Choinani, M., Nighojkar A., and Naik S.., Anal. Chem. Acta., (1986) 15, 49.

6. Bowtle W. Prince P. and Mortimer D., Analyst, (1981), 106, 478; Chem. Abst., 95, 68086z.

7. Murali V., Nageswara R., Rama T. and Sastry P.. Indian Journal of Chem. Technol., ( 2005) 12, 170.

8. Khalil R. and Saeed Ab. J. of Chineese Chemical Society, (2007), 54, 1099-1105.

9. Shingbal D. and Rao V., Indian Drugs, (1985), 22, 275; Chem. Abst., 103, 92947K.

10. Buitrago A., Gonzlez S., Galdern G. and Laura M. Revista de la Facultad de Farmacia, (2005), 47, 10.

11. Shingbal D. and Sardesai G., Indian's Drugs, (1987), 24, 417.

12. Shingbal D., and Kudchadkar H., Indian's Drugs, (1987), 24, 311. 
13. Emmanvel J. and Matheus R., Indans Drugs, (1985), 22, 387; Chem. Abst., 103, 129154C.

14. Gangwal S. and Trivedi P.. Indian J. of Pharmaceutical Sciences, (1999), 61, 128

15. Habib H., Hassouna M. and Zaki G. Farmaco, (2005), 60, 249.

16. Bladyga, J. and Bourne, J. R., "Turbulent Mixing and Chemical Reactions", John Wiley and Sons, Inc., New York, (1999) p. 644. 